\title{
Knowledge Transfer in Strategic Networks: A Systematic Review and Theoretical Propositions
}

\author{
Zhan Wang \\ School of Economics and Management, Shanxi University, Taiyuan, Shanxi, 030006, China
}

\begin{abstract}
The research is financed by Soft Science Research Project in Shanxi Province of China, No. 2018041041-2
\end{abstract}
\section{Abstract}

Knowledge has been recognized the one of the most important resources to obtain competitive advantages for firms. The inter-firm knowledge transfer is considered as the effective way to obtain knowledge. This study firstly provides a comprehensive review of relevant literatures in terms of knowledge transfer and strategic networks. Moreover, this study develops the theoretical propositions regarding the relationship between learning motivation, learning capability and knowledge transfer in strategic networks.

Keywords: Knowledge transfer, strategic network, learning motivation, learning capability

DOI: $10.7176 / \mathrm{EJBM} / 11-21-15$

Publication date:July $31^{\text {st }} 2019$

\section{Introduction}

Knowledge has become one of the key resources to obtain competitive advantages. In a complicated and varying environment, organizations need to continuously study and obtain knowledge in order to construct core competence vis-à-vis their own competitive advantages. To secure sustainable competitive advantage, academics and practitioners are seeking various ways to improve the efficiency and effectiveness of acquiring knowledge, which extends beyond the individual firm's boundaries. Instead, inter-firm knowledge transfer in several forms of business networks is currently considered an effective way to obtain knowledge. Therefore, enterprises are increasingly sharing and transferring knowledge by constructing cooperative networks to enhance the competitive advantages of their own and whole networks. Accordingly, this paper provides analysis and research concerning knowledge transfer within a strategic network.

Firstly, this paper provides an overview of the most relevant literature concerned with knowledge transfer and strategic networks, introducing the concept of knowledge and subsequently defining and explaining knowledge transfer. This part also defines strategic networks and highlights their relevant elements.

According to Simonin (2004), the fundamental steps of knowledge transfer in strategic network is from motivation to learn, capacity to learn to learning outcome. Therefore, the proposed research aims to develop theoretical propositions, explaining the key organizational mechanisms that enable inter-firm knowledge transfer process in strategic networks.

\section{Strategic Networks}

From the perspective of strategy, strategic networks are conceptualized by Jarillo as "long-term, purposeful arrangements among distinct but related for profit organizations" (Jarillo 1988, p.32). The purpose is to enable firms in the network to gain and sustain competitive advantage in order to compete with their competitors outside the network. This view highlights that the strategic networks, the "organizational forms" between the markets and hierarchies, represent a corporate's source of competitive advantage. Furthermore, Jarillo (1988) indicates that "the hub firm", namely that which sets up the network with a pro-active attitude, is the essence of a strategic network.

From the perspective of components of network organizations, Gulati $(2000$, p.204) defined the strategic network as a composition of stable "inter-organizational ties", including long-term buyer-supplier partnerships, joint ventures, strategic alliance and a host of similar ties, which are enduring and strategically significant for the networks. According to this definition, strategic networks encompass horizontal and vertical relationships with other organizations, including their suppliers, customers, competitors and other relationships across industries and countries. Furthermore, the authors emphasize that the theory of strategic networks should be incorporated into the strategy research, given that a strategic network reflects the social context in which firms are embedded, and this social context, which can be classified as a range of "structural, cognitive, institutional, and cultural" elements , can influence the firms' behaviors and performance (Gulati et al., 2000).

From the perspective of social networks, an optimal sized entity that satisfies the critical capacity requirements and focuses on its core competence area obtains other "value-added chains" of strategic partners. Indeed, these interlocking relationships can be termed as strategic networks (Levin, 1998). This point treats a strategic network as a long-term and stable corporation relationship that includes economic and social relationships, and also emphasizes the importance of strategic partnerships, social economic relations and interlocking relationships within the strategic network. 
From the perspective of the combination of strategic networks and information technology, Dale (2003) describes the strategic networks as "a virtual cluster" (Dale 2003, p.111), which means an e-business community comprising customers, suppliers, distributors and commerce providers sharing digital and knowledge networks for the purpose of collaboration and competition (Dale, 2003).

From the perspective of organizational behavior, Borch and Arthur (1995) consider a strategic network as an investment with the purpose of exchanging and sharing information and resources among cooperative firms. They note that a strategic network reflects the socio-economic relations of corporation, trust, input and reciprocity. Moreover, social bonds are elements in creating trust, reciprocity and commitment among the firms in the network. Accordingly, socio-economic relations and trust can play significant roles in a strategic network (Borch and Arthur, 1995).

From the classifications of strategic networks' definitions, while there are different understandings of strategic networks exist based on different focuses and ranges of research, all of them all of them encompass the following characteristics, which differ from normal cooperation among firms.

1. Strategic

A strategic network is built from a strategic perspective by organizations that expect to gain and sustain their own core competence based on the overall advantages of the strategic network.

2. Long-term

Strategic networks focus on the long-term benefits of cooperation rather than the immediate interests.

3. Cooperation and competition

Strategic networks emphasize the cooperation of internal organizations in the network and competition with other organizations outside the network.

4. Integrity

The object of management in a strategic network is the whole network, as opposed to any particular organization. 5. Strategic Centre Firm

A strategic network is developed around one center firm, which has greater strength compared with the other organizations. The center firm can be perceived as the manager with the ability to maintain relationships within the network.

Based on the literature synthesis of strategic networks' definitions, this article proposes the following definition of the term "strategic network". In order to achieve a common goal, a strategic centre firm and other organizations (including firms, institutions, agencies, etc.) establish a long-term, mutual trusting and interdependent relationship of resource sharing and business interactions based upon formal and informal contracts. The relationship includes vertical (such as suppliers, customers, intermediary agencies, etc.) and horizontal relationship (such as competitors, firms of other industries, etc.), and the strategic network competes with competitors outside the network with the whole network's competence.

\section{Knowledge transfer}

\subsection{Definition of knowledge transfer}

The predecessor of knowledge transfer is technology transfer, which first appeared in Teece's academic article in 1977. Indeed, he believes that the successful international transfer of technology can lead to increasing the stock of using knowledge and the extension of its application (Teece, 1977). Scholars have subsequently introduced technology transfer into knowledge management research, eliciting the idea of knowledge transfer in order to describe, explain and research the transfer of knowledge in different organizations. Despite the concept of knowledge transfer being simple, different scholars define knowledge transfer according to different emphasis, and this chapter attempts to bring some clarity by dividing concepts of knowledge transfer into three categories: The first category of definitions emphasizes that knowledge transfer is a process (see Table 1), identified as cognitive, dynamic, iterative and exchanging (Tang et al., 2010, Bond et al., 2008, Szulanski, 1996, Garavelli et al., 2002, Gilbert and CordeyHayes, 1996).

Table 1. Definition of knowledge transfer emphasizing the process

\begin{tabular}{|l|l|l|}
\hline Author & Key words & Description \\
\hline Szulanski (1996) & an exchanging process & dyadic exchanges of knowledge \\
\hline $\begin{array}{l}\text { Gilbert and CordeyHayes } \\
(1996)\end{array}$ & a dynamic process & part of a process of continuous learning \\
\hline Garavelli et al. (2002) & two main cognitive processes & codification and interpretation \\
\hline Tang et al. (2010) & an iterative process & a process between knowledge senders and recipients \\
\hline Geraghty and Desouza (2005) & a process & movement of knowledge created from one to another \\
\hline Bond et al. (2008) & $\begin{array}{l}\text { an interactive and dynamic } \\
\text { process }\end{array}$ & $\begin{array}{l}\text { specialized participants absorb, assimilate, emit and } \\
\text { exchange knowledge }\end{array}$ \\
\hline
\end{tabular}

The second category of definitions focuses on the contents of knowledge transfer, with Garavellia (2002) indicating that it supports both the knowledge codification and interpretation, which represents the upstream and 
downstream part of the process, respectively. In Xiao and Liu's opinion, the content of knowledge transfer involves the transmission of knowledge in different organizations and individuals in different ways (Xiao and Liu, 2006).

The third category of definitions focuses on the benefits for both sides in knowledge transfer. When contributors share knowledge used by adopters, knowledge transfer has occurred (Darr and Kurtzberg, 2000). Within this process, one unit (the receiver) is affected by the experience of another (the source), and particularly the communication between a source and recipient leads the learning and application of knowledge to the recipient (Argote and Ingram, 2000, Ko et al., 2005). More importantly, as a part of resource ties, knowledge transfer can create new knowledge, provide opportunities to utilize it and contribute to the innovation ability for interpersonal cooperation (Cater, 2007, Lin and Li, 2010).

Despite scholars defining knowledge transfer from different perspectives, the following definitions reflect some consensus. Firstly, knowledge transfer is a process that transfers knowledge from a source to receiver. Secondly, knowledge transfer includes the receiver's absorption of knowledge and the feedback to the source, and the transmission and absorption of knowledge cannot be separated from each other. And thirdly, the purpose of knowledge transfer is to let the receiver learn and apply the knowledge from the source.

Synthesizing the analysis above, this paper defines knowledge transfer as the process including the transmission and absorption of knowledge from a source to receiver. The absorption of knowledge implies the full understanding and application of knowledge.

\subsection{Previous studies of knowledge transfer}

Previous studies can be classified into two groups; one investigating the antecedents of knowledge transfer; and another exploring the relationships between knowledge transfer and organizational performance.

The first category of studies explores the antecedents of knowledge transfer, which can be classified according to three classes. Table 2 provides a synthesis of previous studies of knowledge transfer.

Table 2 A Synthesis of Empirical Studies of Antecedents of Inter-firm Knowledge Transfer

\begin{tabular}{|c|c|c|c|}
\hline Author & Focus & Data collection & Results and outcomes \\
\hline \multicolumn{4}{|c|}{ Antecedents: sources and recipients-related factors } \\
\hline $\begin{array}{l}\text { Cohen and } \\
\text { Levinthal } \\
(1990)\end{array}$ & $\begin{array}{l}\text { Inter-firm } \\
\text { relationship }\end{array}$ & $\begin{array}{l}\text { Survey in } 1719 \text { business units } \\
\text { representing } 318 \text { firms in the U.S. }\end{array}$ & $\begin{array}{l}\text { R\&D activities of enhance firm's absorptive } \\
\text { capacity for exploiting external knowledge. }\end{array}$ \\
\hline $\begin{array}{l}\text { Hamel } \\
(1991)\end{array}$ & $\begin{array}{l}\text { International } \\
\text { strategic } \\
\text { alliances } \\
\end{array}$ & $\begin{array}{l}\text { Interviews with } 74 \text { individuals } \\
\text { across } 11 \text { companies in the U. S., } \\
\text { Japan and European Community }\end{array}$ & $\begin{array}{l}\text { Transparency, intent and receptivity are principal } \\
\text { determinants of learning process. }\end{array}$ \\
\hline $\begin{array}{l}\text { Cummings } \\
\text { and Teng } \\
(2003)\end{array}$ & $\begin{array}{l}\text { Employees, } \\
\text { R\&D partners }\end{array}$ & $\begin{array}{l}\text { Survey to } 861 \text { employees from } 15 \\
\text { industries in the United States }\end{array}$ & $\begin{array}{l}\text { The increase of organizational, physical, or } \\
\text { knowledge distance between source and recipient } \\
\text { can decrease transfer success. }\end{array}$ \\
\hline $\begin{array}{l}\text { Ko et al. } \\
\text { (2005) }\end{array}$ & ERP system & $\begin{array}{l}\text { Survey to } 96 \text { ERP projects in } 80 \\
\text { client organizations and } 38 \\
\text { consulting firms in the U.S. }\end{array}$ & $\begin{array}{l}\text { Absorptive capacity, shared understanding, } \\
\text { intrinsic motivation and credibility of source } \\
\text { positively related to the knowledge transfer. }\end{array}$ \\
\hline \multicolumn{4}{|c|}{ Antecedents: knowledge-related factors } \\
\hline $\begin{array}{l}\text { Simonin } \\
(1999)\end{array}$ & $\begin{array}{l}\text { Strategic } \\
\text { alliances }\end{array}$ & $\begin{array}{l}\text { Survey in } 151 \text { multinationals in the } \\
\text { U.S. }\end{array}$ & $\begin{array}{l}\text { Tacitness is the most important determinant of } \\
\text { knowledge transfer. }\end{array}$ \\
\hline $\begin{array}{l}\text { Cummings } \\
\text { and Teng } \\
(2003)\end{array}$ & $\begin{array}{l}\text { Employees, } \\
\text { R\&D partners }\end{array}$ & $\begin{array}{l}\text { Survey to } 861 \text { employees from } 15 \\
\text { industries in the U.S. }\end{array}$ & $\begin{array}{l}\text { Knowledge transfer success increases because } \\
\text { embedded knowledge decreases and articulable } \\
\text { knowledge increase. }\end{array}$ \\
\hline \multicolumn{4}{|c|}{ Antecedents: context-related factors } \\
\hline $\begin{array}{l}\text { Duanmu } \\
\text { and Fai } \\
(2007)\end{array}$ & $\begin{array}{l}\text { Multinational } \\
\text { firms }\end{array}$ & $\begin{array}{l}16 \text { dyadic case studies using a } \\
\text { process-oriented approach in China }\end{array}$ & $\begin{array}{l}\text { The main factors that influence the knowledge } \\
\text { transfer process include business culture, } \\
\text { language difference, levels of trust, and } \\
\text { partnership. }\end{array}$ \\
\hline $\begin{array}{l}\text { Ei-sayed } \\
(2002)\end{array}$ & $\begin{array}{l}\text { Multinational } \\
\text { firms }\end{array}$ & $\begin{array}{l}\text { Secondary data with ontology } \\
\text { based approach }\end{array}$ & $\begin{array}{l}\text { The effectiveness of inter-firm knowledge } \\
\text { transfer process is related to the degree of culture } \\
\text { heterogeneity between the firms involved. }\end{array}$ \\
\hline $\begin{array}{l}\text { Mowery et } \\
\text { al. (1996) }\end{array}$ & $\begin{array}{l}\text { Strategic } \\
\text { alliance }\end{array}$ & $\begin{array}{l}792 \text { Bilateral alliances that } \\
\text { involved at least one U.S firm. }\end{array}$ & $\begin{array}{l}\text { The cultural differences impede inter-firm } \\
\text { knowledge transfer. }\end{array}$ \\
\hline $\begin{array}{l}\text { Weber and } \\
\text { Weber } \\
(2007)\end{array}$ & $\begin{array}{l}\text { Joint venture } \\
\text { company }\end{array}$ & $\begin{array}{l}\text { Interview with } 12 \text { investment } \\
\text { professionals of } 7 \text { selected CVCs } \\
\text { and } 20 \text { joint venture PCs in } \\
\text { Germany }\end{array}$ & $\begin{array}{l}\text { Knowledge sharing routine, effective } \\
\text { communication, willingness and trust positively } \\
\text { influence the knowledge transfer process. }\end{array}$ \\
\hline
\end{tabular}

The first class involves investigating the relationship between knowledge-related factors (tacit and explicit) and knowledge transfer. Secondly, some other researchers explore the source and recipient-related factors than can facilitate or hinder the knowledge transfer. Finally, a growing number of studies investigate the effect of contextrelated factors on the knowledge transfer process, given that it is embedded in an organizational, social and 
relational context. The most influential context-related factors include organizational culture, organizational structure, information technology and reward system. For the reward system, some authors suggest that reward systems are required in order to facilitate knowledge transfer. However, it is necessary to consider the problem of individual- or group-based rewards. For example, through a survey and qualitative analysis in a Korean firm, Lee and Ahn (2007) indicate that group-based reward is less efficient than individual-based reward in encouraging knowledge sharing behavior among employees within an organization.

The second category of studies investigates the relationships between knowledge transfer and organizational performance, towards the purpose of sharpening the understanding of the effects of knowledge transfer on organizational performance. Previous studies have shown that knowledge transfer contributes to the achievement of organizational innovation, effectiveness and performance, either directly or indirectly (Yang, 2007, Lee and Choi, 2003, Lai and Lee, 2007, Gold et al., 2001, Darroch, 2005, Yang et al., 2011). For example, Yang et al. (2011) propose that social capital influences selling center performance through facilitating knowledge transfer within the selling center.

\section{Learning Motivation-Learning Capacity-Knowledge Transfer \\ 4.1 Learning motivation and knowledge transfer}

Previous studies have emphasized that the presence of learning motivation in the receiver organizations represents the first important step and prerequisite towards knowledge transfer and learning (Hamel, 1991, Tsang, 2002, Hau and Evangelista, 2007, Inkpen and Dinur, 1998). Learning motivation is defined within current research as the degree of desire and will of receiver organizations to learn and internalize the skills and competencies from the source organizations (Hamel, 1991, Tsang, 2002, Simonin, 2004). Firms have numerous reasons for entering into a strategic network, with a desire to learn from their partner often representing a major factor (Tsang, 1999). However, in a strategic network, realizing that the partners possess valuable knowledge, different firms in the network are likely to exert diverse level of motivation in relation to such knowledge (Hau and Evangelista, 2007). By analyzing several Western-Japanese alliances, Hamel (1991) indicates that learning motivation may influence the allocations of organizational resource to learn new knowledge from the partners. According to his study, some firms are only interested in using the strategic networks as a substitute to gain access to the knowledge from a partner, while other firms seek acquiring knowledge from their partner aggressively. Consequently, while the former may acquire the lower valuable knowledge from their partners, the latter, which may have stronger motivation in viewing "competitiveness as competence-based, rather than as product-based", seek to "close the skill gaps rather than compensate for skill failure" (Hamel 1991, p.87). In the same vein, Hau and Evangelista's (2007) study provides empirical evidence emphasizing the positive direct influences of learning motivation on knowledge transfer in both tacit and explicit forms, by examining 219 International Joint Ventures in Vietnam. Similarly, Perez-Nordtvedt et al. (2008) empirically propose that the learning intent of receiver firms is positively related to the speed and understanding of knowledge transferred from the source firms. Consequently, if a firm has the motivation to learn, it can do so better and faster (Hau and Evangelista, 2007, Perez-Nordtvedt et al., 2008).

A strong desire to acquire partners' skill and competencies represents the major motive behind the effort and the first significant step is to remove the barrier hindering such resource allocation for learning (Kim, 1998, Tsang, 2002, Park and Ghauri, 2011). Accordingly, learning motivation is the first step to effectively transfer knowledge, and could heighten the firm's awareness of learning needs, which can be identified as the major determinant towards learning (Hamel, 1991, Inkpen and Dinur, 1998, Inkpen, 2000, Hau and Evangelista, 2007).

Proposition 1: Learning motivation is positively related to knowledge transfer.

\subsection{Learning capacity and knowledge transfer}

As suggested by Simonin (2004, p.410), learning capacity is the "actionable side" of absorptive capacity. It is related with, yet also distinct from, absorptive capacity. Absorptive capacity was originally recognized as an organizational capability to recognize and assimilate the external knowledge and apply it to commercial ends (Cohen and Levinthal, 1990, Zahra and George, 2002). Empirical research has focused on the role of absorptive capacity in organizational outcomes (Perez-Nordtvedt et al., 2010), such as knowledge transfer level and performance (Cohen and Levinthal, 1990, Kim and Inkpen, 2005, Lane and Lubatkin, 1998, Tsai, 2001, Zahra and George, 2002). In the context of learning alliances, Simonin (2004) highlights that researchers' focus on the "partner-specific" absorptive capability, which emphasizes the similarity and overlap between partners. By comparison, learning capacity is focused on firm-specific resources that can be manipulated and deployed to enhance the efficiency of a learning process. Simonin (2004 p.410) labels learning capacity as a "fundamental determinant of absorptive capacity."

Simonin (2004) decomposes learning capacity into three separate components based on the three factors of receptivity within Hamel's (1990) research. The receptivity corresponds to the organizational capacity to learn from partners, with the three factors being resource deployment, incentive systems and attitude towards learning (Hamel, 1990). In this respect, three distinct learning capacities that facilitate knowledge transfer in strategic 
networks are "resource-based learning capacity", "incentive-based learning capacity", and "cognitive-based learning capacity" (Simonin 2004, p.410).

4.2.1 Resource-based learning capacity

As recognized by Simonin (2004), resource-based capacity represents to the commitment of both human capital and tangible assets. Human capital theory (Becker, 1993) indicates that employees and managers are firms' precious assets that need to be invested in and treasured (Ling and Jaw, 2006, Yamao et al., 2009). In other words, the collective knowledge, skills, capability, experiences and quality of employees and managers are valuable and unique, and should be kept out of other companies' reach (Ling and Jaw, 2006, p.381). Indeed, organizations with higher levels of human capital tend to possess more effective resources in acquiring and applying knowledge from partners (Variyam and Kraybill, 1993, Simonin, 2004, Park, 2010, Perez-Nordtvedt et al., 2010, Park and Ghauri, 2011). Analyzing 151 Australian subsidiary top managers from the multinational companies in the United States, Germany and Japan, Yamao et al. (2009) represent human capital as knowledge stocks that are positively related to knowledge transfer. Similarly, based upon a sample of 276 SMEs in Italy, Muscio (2007) identifies human capital as the foundation of organizational knowledge base, which can contribute to a firm's capability to acquire new technology.

The next complement of resource-based learning capacity is a tangible asset, namely another support asset to help organizations acquire, apply, store and diffuse valuable knowledge. This support asset can include logistic, financial, and communication capability (Simonin, 2004). Thus, it is expected that resource-based learning capacity can impact knowledge transfer:

Proposition 2a: The resource-based learning capacity is positively related to knowledge transfer.

4.2.2 Incentive-based learning capacity

Simonin (2004, p.411) suggests that incentive-based learning capacity relates to "explicit institutional routines, systems, rules and guidelines that clarify individual expectations and duties, steer learning activities in nonambiguous terms, foster a learning orientations, and induce commitment to a learning objective." In particular, Simonin (2004) considers Pucik's (1988) two specific manifestations that are recognized as the enablers or obstacles of organizational learning in alliances: an actual reward system and a clear learning agenda.

An actual and formal reward system is one of main components enhancing the motivation to share and acquire knowledge. While practices of reward systems can trigger and improve knowledge acquisition and dissemination, conversely, the lack of formal reward systems may inhibit knowledge-sharing initiatives due to people's reluctance to assimilate and share knowledge (Simonin and Ozsomer, 2009, O'Dell and Grayson, 1998, Jahani et al., 2011). Rewards could range from monetary incentives to non-monetary awards, which should be given to employees who spend time facilitating and working with acquiring sharing knowledge (Wang and Lim, 2008, Song, 2009). Indeed, such a reward system can be recognized as an organizational support that can reduce barriers of knowledge sharing and support individual learning (Riege, 2007).

Despite a few studies suggesting that reward systems can also have a counterproductive influence on organizational performance (Pearce et al., 1985), most research has shown that reward systems involve a positive motivation to organizational performance. For example, Fey and Furu (2008) identify a positive relationship between subsidiary bonus and knowledge sharing through studying 164 foreign-owned subsidiaries located in Finland and China.

In addition to an actual reward system, a learning agenda is also required in order to transfer effectively. Accordingly, Von Krogh et al. (2000) insists that organizations have to specifically identify the knowledge that they need to seed and create. Therefore, building on Pucik's (1988) theory, Simonin (2004) suggests that in order to enhance the organizational performance, a learning agenda should be centered around the learning process, with a clear definition and codification that can be communicated to the relevant units. Accordingly, incentive-based learning capacity is anticipated to drive the knowledge transfer:

Proposition 2b: The incentive-based learning capacity is positively related to knowledge transfer.

4.2.3 Cognitive-based learning capacity

The final component of learning capacity, namely cognitive-based learning capacity, can be figured as the "general attitudes and beliefs towards learning that prevail in the organization" (Simonin 2004, p.411). Here, attitudes capture the degree of one's feeling about acquiring knowledge (Bock et al., 2005). Simonin's (2004) paper identifies that the effect of cognitive-based learning capacity on knowledge transfer depends on context factors, providing empirical evidence that cognitive-based learning capacity only positively and directly affect on knowledge transfer in non-competitive and non-equity based alliances. As with resource-based and incentivebased learning capacity, cognitive-based learning capacity is expected to affect the knowledge transfer:

Proposition 2c: The cognitive-based learning capacity is positively related to the knowledge transfer.

\subsection{Learning motivation and learning capacity}

The link between learning motivation and learning capacity is based on the premise that once receiver and acquirer firms have conscious interests in transferring knowledge, it can develop a mechanism to make sure that staffs in 
the receiver firm are able to learn new knowledge (Tsang, 2001, Inkpen and Tsang, 2005, Hau and Evangelista, 2007). In this respect, such staffs should have an appropriate educational background and be skilled in learning with both formal training and practical work. Moreover, the mechanisms also ensure that the firm's tangible resource deployment could provide sufficient support to acquire knowledge (Simonin, 2004).

Furthermore, Simonin (2004) indicates that learning intent does not simply translate into appropriate human and tangible resource deployment; rather, it is also expected to influence individual motivation and commitment of learning. Learning motivation can foster the motivation to learning from intrinsic to extrinsic (Mohr and Sengupta, 2002). For instance, when learning is valued for its own sake, the intrinsic motivation occurs (Hau and Evangelista, 2007); whereas extrinsic motivation is derived from the external sources, like the incentive and compensation (Ko et al., 2005). In the context strategic network, if individuals of the receiver firm are motived to learn from their partners with a reward system, they can effectively acquire knowledge (Hurley, 2002, Hau and Evangelista, 2007). Besides an actual reward system, a learning agenda is also related to learning motivation. Accordingly, it is necessary to explicitly make the motivation of organizational learning in words and propose to employees in order to foster their commitment (Nonaka and Takeuchi, 1995).

Finally, Simonin (2004) also reveals that learning motivation is conducive to cognitive-based learning capacity. In this sense, a receiver firm with learning motivation can their employees to learn, and thus, cognitivebased learning capacity can be strengthened through the right impetus, such as learning motivation.

Therefore, this paper expects that all of the three components of learning capacity are positively influenced by learning motivation:

Proposition 3: Learning motivation is positively related to the (a) resource-based learning capacity, (b) incentivebased learning capacity, and (c) cognitive-based learning capacity.

\section{Moderators}

Given that the context lies in the network, this study chooses moderators at the dyadic inter-organizational level and network level. Governance mode is selected as the dyadic inter-organizational level moderator (Phelps et al., 2012). In light of Simonin's view, two modes of governance can be categorized (partnering network and contracting network (Fey, 2005)), which have "different underlying governance properties that affect their functioning" (Zollo et al., 2002, p.704). Partnering refers to acquiring knowledge through relationships with specific partner firms such as joint ventures or university collaborations, while contracting refers to obtaining knowledge via market-based transaction (Fey, 2005). Therefore, it is reasonable to expect that the outcome of knowledge transfer can differ across these two modes. In comparison with contracting network relationships, partnering network relationships such as joint ventures are argued to be more effective in facilitating knowledge transfer (Kogut, 1988, Mowery et al., 1996, Lane and Lubatkin, 1998, Oxley and Sampson, 2004, Jiang and Li, 2008). This is because, compared to contract-based forms, partner-based networks involve a higher level of communication, trust and interdependence among partners, thus enabling a better opportunity for inter-firm learning (Jiang and Li, 2008).

Proposition 4: The above relationships are moderated by the two modes of governance.

At the network level, network structure represents the pattern of relationships between network nodes (Gulati et al., 2000), where every node has a different position in a strategic network. As mentioned in Section 2, a strategic network is organised around a centre firm, which has a pro-active attitude and greater strength than the other organizations (Lorenzoni and Badenfuller, 1995, Jarillo, 1988). Other organizations have direct and indirect relationships with the centre firm. These relationships can be divided into vertical relationships (with suppliers, customers and distributors) and horizontal relationships (with government, universities, research institutions, etc.). Network structure is considered as the moderator of the entire network; three elements of it can be categorized as "strategic centre firm", "vertical partner" and "horizontal partner".

Proposition 5: The above relationships are moderated by the three elements of network structure.

\section{References}

Argote, L. \& Ingram, P. 2000. Knowledge transfer: A basis for competitive advantage in firms. Organizational Behavior and Human Decision Processes, 82, 150-169.

Becker, G. 1993. Human capital: a theoretical and empirical analysis, with special reference to education, Chicago, The University of Chicago Press.

Bock, G. W., Zmud, R. W., Kim, Y. G. \& Lee, J. N. 2005. Behavioral intention formation in knowledge sharing: Examining the roles of extrinsic motivators, social-psychological forces, and organizational climate. Mis Quarterly, 29, 87-111.

Bond, E. U., Houston, M. B. \& Tang, Y. H. 2008. Establishing a high-technology knowledge transfer network: The practical and symbolic roles of identification. Industrial Marketing Management, 37, 641-652.

Borch, O. J. \& Arthur, M. B. 1995. Strategic Networks among Small Firms - Implications for Strategy Research Methodology. Journal of Management Studies, 32, 419-441. 
Cater, B. 2007. Adaptation, Co-operation and Knowledge Transfer in Relationships Between Marketing Research Providers and Their Clients: The Case of Slovenia. Economic and Business Review, 9, 191-212.

Cohen, W. M. \& Levinthal, D. A. 1990. Absorptive-Capacity - a New Perspective on Learning and Innovation. Administrative Science Quarterly, 35, 128-152.

Cummings, J. L. \& Teng, B. S. 2003. Transferring R\&D knowledge: the key factors affecting knowledge transfer success. Journal of Engineering and Technology Management, 20, 39-68.

Dale, C. 2003. The Competitive Networks of Tourism E-mediaries: New Strategics, New Advantages. Journal of Vacation Marketing, 9, 109-118.

Darr, E. D. \& Kurtzberg, T. R. 2000. An investigation of partner similarity dimensions on knowledge transfer. Organizational Behavior and Human Decision Processes, 82, 28-44.

Darroch, J. 2005. Knowledge Management, Innovation and Firm Performance. Journal of Knowledge Management, 9, 101-115.

Duanmu, J. L. \& Fai, F. M. 2007. A processual analysis of knowledge transfer: From foreign MNEs to Chinese suppliers. International Business Review, 16, 449-473.

Ei-sayed, A. 2002. An Ontology-Based Approach to Inter-organizational Knowledge Transfer. Journal of Global Information Technology Management, 5, 32-47.

Fey, C. F. 2005. External sources of knowledge, governance mode, and R\&D performance. Journal of Management, 31, 597-621.

Fey, C. F. \& Furu, P. 2008. Top Management Incentive Compensation and Knowledge Sharing in Multinational Corporations. Strategic Management Journal, 29, 1301-1323.

Garavelli, A. C., Gorgoglione, M. \& Scozzi, B. 2002. Managing knowledge transfer by knowledge technologies. Technovation, 22, 269-279.

Geraghty, K. \& Desouza, K. C. 2005. Optimizing knowledge networks. Industrial Management, 47, 25-30.

Gilbert, M. \& CordeyHayes, M. 1996. Understanding the process of knowledge transfer to achieve successful technological innovation. Technovation, 16, 301-312.

Gold, A. H., Malhotra, A. \& Segars, A. H. 2001. Knowledge management: An organizational capabilities perspective. Journal of Management Information Systems, 18, 185-214.

Gulati, R., Nohria, N. \& Zaheer, A. 2000. Strategic networks. Strategic Management Journal, 21, $203-215$.

Hamel, G. 1990. Competitive collaboration: learning, power and dependence in international strategic alliances. $\mathrm{PhD}$, University of Michigan.

Hamel, G. 1991. Competition for Competence and Inter-Partner Learning within International Strategic Alliances. Strategic Management Journal, 12, 83-103.

Hau, L. N. \& Evangelista, F. 2007. Acquiring tacit and explicit marketing knowledge from foreign partners in INS. Journal of Business Research, 60, 1152-1165.

Hurley, R. 2002. Putting people back into organizational learning. Journal of Business \& Industrial Marketing, 17, $270-281$

Inkpen, A. C. 2000. Learning through joint ventures: A framework of knowledge acquisition. Journal of Management Studies, 37, 1019-1043.

Inkpen, A. C. \& Dinur, A. 1998. Knowledge management processes and international joint ventures. Organization Science, 9, 454-468.

Inkpen, A. C. \& Tsang, E. W. K. 2005. Social capital, networks, and knowledge transfer. Academy of Management Review, 30, 146-165.

Jahani, S., Ramayah, T. \& Effendi, A. 2011. Is reward system and leadership important in knowledge sharing among academics? American Journal of Economics and Business Administration, 3, 87-94.

Jarillo, J. C. 1988. On Strategic Networks. Strategic Management Journal, 9, 31-41.

Jiang, X. \& Li, Y. 2008. The relationship between organizational learning and firms' financial performance in strategic alliances: A contingency approach. Journal of World Business, 43, 365-379.

Kim, C. \& Inkpen, A. 2005. Cross-border R\&D alliances, absorptive capacity and technology learning. Journal of International Management, 11, 313-329.

Kim, L. 1998. Crisis construction and organizational learning: Capability building in catching-up at Hyundai Motor. Organization Science, 9, 506-521.

Ko, D. G., Kirsch, L. J. \& King, W. R. 2005. Antecedents of knowledge transfer from consultants to clients in enterprise system implementations. Mis Quarterly, 29, 59-85.

Kogut, B. 1988. Joint Ventures - Theoretical and Empirical-Perspectives. Strategic Management Journal, 9, 319332.

Lai, M. F. \& Lee, G. G. 2007. Relationships of Organizational Culture Toward Knowledge. Business Process Management Journal, 13, 206-217.

Lane, P. J. \& Lubatkin, M. 1998. Relative absorptive capacity and interorganizational learning. Strategic Management Journal, 19, 461-477. 
Lee, D. J. \& Ahn, J. H. 2007. Reward Systems for Intra-organizational Knolwedge Sharing. European Journal of Operational Research, 180, 938-956.

Lee, H. \& Choi, B. 2003. Knowledge management enablers, processes, and organizational performance: An integrative view and empirical examination. Journal of Management Information Systems, 20, 179-228.

Levin, B. M. 1998. Strategic networks: The emerging business organization and its impact on production costs. International Journal of Production Economics, 56-7, 397-405.

Lin, M. \& Li, N. 2010. Scale-free network provides an optimal pattern for knowledge transfer. Physica a-Statistical Mechanics and Its Applications, 389, 473-480.

Ling, Y. H. \& Jaw, B. S. 2006. The influence of international human capital on global initiatives and financial performance. International Journal of Human Resource Management, 17, 379-398.

Lorenzoni, G. \& Badenfuller, C. 1995. Creating a Strategic Center to Manage a Web of Partners. California Management Review, 37, 146-163.

Mohr, J. J. \& Sengupta, S. 2002. Managing the paradox of interfirm learning: the role of governance mechanisms. Journal of Business \& Industrial Marketing, 17, 282-301.

Mowery, D. C., Oxley, J. E. \& Silverman, B. S. 1996. Strategic alliances and interfirm knowledge transfer. Strategic Management Journal, 17, 77-91.

Muscio, A. 2007. The impact of absorptive capacity on SMEs' collaboration. Economic of Innovation \& New Technology, 16, 653-668.

Nonaka, I. \& Takeuchi, H. 1995. The knowledge-creating company: how Japanese companies create the dynamics of innovation, New York, Oxford University Press.

O'Dell, C. \& Grayson, C. J. 1998. If only we knew what we know: Identification and transfer of internal best practices. California Management Review, 40, 154-+.

Oxley, J. E. \& Sampson, R. C. 2004. The scope and governance of international R\&D alliances. Strategic Management Journal, 25, 723-749.

Park, B. I. 2010. What matters to managerial knowledge acquisition in international joint ventures? High knowledge acquirers versus low knowledge acquirers. Asia Pacific Journal of Management, 27, 55-79.

Park, B. I. \& Ghauri, P. N. 2011. Key factors affecting acquisition of technological capabilities from foreign acquiring firms by small and medium sized local firms. Journal of World Business, 46, 116-125.

Pearce, J. L., Stevenson, W. B. \& Perry, J. L. 1985. Managerial Compensation Based on Organizational Performance - a Time-Series Analysis of the Effects of Merit Pay. Academy of Management Journal, 28, 261278.

Perez-Nordtvedt, L., Babakus, E. \& Kedia, B. L. 2010. Learning from international business affiliates: developing resource-based learning capacity through networks and knowledge acquisition. Journal of International Management, 16, 262-274.

Perez-Nordtvedt, L., Kedia, B. L., Datta, D. K. \& Rasheed, A. A. 2008. Effectiveness and efficiency of crossborder knowledge transfer: An empirical examination. Journal of Management Studies, 45, 714-744.

Phelps, C., Heidl, R. \& Wadhwa, A. 2012. Knowledge, Networks, and Knowledge Networks: A Review and Research Agenda. Journal of Management, 38, 1115-1166.

Pucik, V. 1988. Strategic Alliances, Organizational Learning, and Competitive Advantage - the Hrm Agenda. Human Resource Management, 27, 77-93.

Riege, A. 2007. Actions to overcome knowledge transfer barriers in MNCs. Journal of Knowledge Management, $11,48-67$.

Simonin, B. L. 1999. Transfer of marketing know-how in international strategic alliances: An empirical investigation of the role and antecedents of knowledge ambiguity. Journal of International Business Studies, 30, 463-490.

Simonin, B. L. 2004. An empirical investigation of the process of knowledge transfer in international strategic alliances. Journal of International Business Studies, 35, 407-427.

Simonin, B. L. \& Ozsomer, A. 2009. Knowledge Processes and Learning Outcomes in Mncs: An Empirical Investigation of the Role of Hrm Practices in Foreign Subsidiaries. Human Resource Management, 48, 505530.

Song, D. 2009. The tacit knowledge-sharing strategy analysis in the project work. International Business Research, 2,83 .

Szulanski, G. 1996. Exploring internal stickiness: Impediments to the transfer of best practice within the firm. Strategic Management Journal, 17, 27-43.

Tang, F. C., Mu, J. F. \& MacLachlan, D. L. 2010. Disseminative capacity, organizational structure and knowledge transfer. Expert Systems with Applications, 37, 1586-1593.

Teece, D. J. 1977. Technology-Transfer by Multinational Firms - Resource Cost of Transferring Technological Know-How. Economic Journal, 87, 242-261.

Tsai, W. P. 2001. Knowledge transfer in intraorganizational networks: Effects of network position and absorptive 
capacity on business unit innovation and performance. Academy of Management Journal, 44, 996-1004.

Tsang, E. 2001. Managerial learning in foreign-invested enterprises of China. Management International Review, 41, 29-51.

Tsang, E. W. K. 1999. A preliminary typology of learning in international strategic alliances. Journal of World Business, 34, 211-229.

Tsang, E. W. K. 2002. Acquiring knowledge by foreign partners from international joint ventures in a transition economy: Learning-by-doing and learning myopia. Strategic Management Journal, 23, 835-854.

Variyam, J. N. \& Kraybill, D. S. 1993. Small Firms Choice of Business Strategies. Southern Economic Journal, 60, 136-145.

Von Krogh, G., Ichiro, K. \& Nonaka, I. 2000. Enabling knowledge creation, Oxford, Oxford University Press.

Wang, H. \& Lim, S. S. 2008. Real options and real value: The role of employee incentives to make specific knowledge investments. Strategic Management Journal, 29, 701-721.

Weber, B. \& Weber, C. 2007. Corporate venture capital as a means of radical innovation: Relational fit, social capital, and knowledge transfer. Journal of Engineering and Technology Management, 24, 11-35.

Xiao, H. \& Liu, S. 2006. Study on the Influential Factors of Knowledge Transfer Based on the Dynamic Theory (in Chinese). Modern Management Science, 2006, 9-10.

Yamao, S., De Cieri, H. \& Hutchings, K. 2009. Transferring Subsidiary Knowledge to Global Headquarters: Subsidiary Senior Executives' Perceptions of the Role of $\mathrm{Hr}$ Configurations in the Development of Knowledge Stocks. Human Resource Management, 48, 531-554.

Yang, J. 2007. The Impact of Knowledge Sharing on Organizational Learning and Effectiveness. Journal of Knowledge Management, 11, 83-90.

Yang, J., Alejandro, T. G. B. \& Boles, J. S. 2011. The role of social capital and knowledge transfer in selling center performance. Journal of Business \& Industrial Marketing, 26, 152-161.

Zahra, S. A. \& George, G. 2002. Absorptive capacity: A review, reconceptualization, and extension. Academy of Management Review, 27, 185-203.

Zollo, M., Reuer, J. J. \& Singh, H. 2002. Interorganizational routines and performance in strategic alliances. Organization Science, 13, 701-713. 